\title{
Implementasi Peran Serta Masyarakat Dalam Pembentukan Peraturan Daerah Di Kota Makassar
}

\author{
Muhammad Al Habsy Ahmad \\ Fakultas Hukum, Universitas Tomakaka \\ Koresponden, Email: habsykonoha123@gmail.com
}

\begin{abstract}
ABSTRAK
Tujuan Penelitian untuk menganalisa implementasi Peran serta masyarakat dalam Pembentukan Peraturan daerah di Kota Makassar. Metode penelitian adalah Penulisan ini menggunakan metode penelitian empiric. Hasil Penelitian, implementasi peran serta masyarakat dalam Pembentukan Peraturan daerah di Kota Makassar belum terimplementasi dengan baik. Hal ini didasarkan bahwa dalam kurun waktu 5 tahun terakhir terhitung sejak 2010 sampai dengan 2015 sebanyak 46 peraturan daerah telah dibentuk dan hanya 3 peraturan daerah yang melibatkan masyarakat dalam pembentukan peraturan daerah tersebut. Faktorfaktor yang mempengaruhi implementasi Peran serta masyarakat dalam Pembentukan Peraturan daerah di Kota Makassar adalah faktor pendidikan, faktor pekerjaan, faktor substansi hukum, faktor struktur hukum dan faktor pengetahuan masyarakat. Faktor tersebut menjadi hal utama dalam teralisasinya suatu peraturan daerah dengan baik khususnya peraturan daerah kota Makassar.
\end{abstract}

Kata Kunci: Implementasi; Peran Serta; Masyarakat; Peraturan Daerah

\begin{abstract}
Research Objectives to analyze the implementation of the community in the formation of regional regulation in the city of Makassar The approach is writing it uses research methodology empirical. The result of the research, research methodology is writtend for implementation the role of the community in the formation of regulation areas in the city makassar not allowed well. The results of the study, the implementation of community participation in the formation of local regulations in Makassar City has not been implemented well. This is based on that in the past 5 years from 2010 to 201546 regional regulations have been formed and only 3 regional regulations have involved the community in the formation of these regional regulations. Factors that influence the implementation of community participation in the formation of local regulations in Makassar City are education, employment, legal substance, legal structure and community knowledge. These factors become the main thing in the realization of a local regulation properly, especially the Makassar city regional regulation
\end{abstract}

Keywords: Implementation; Participation; Public; Local regulation 


\section{PENDAHULUAN}

Amandemen Undang-Undang Dasar Negara Republik Indonesia Tahun 1945 (UUD NRI 1945), Peraturan daerah menjadi instrumen Penyelenggaraan otonomi daerah. Pasal 18 ayat (6) hasil Amandement UUD NRI 1945 ditentukan bahwa Pemerintahan daerah berhak menetapkan Peraturan daerah dan Peraturan-peraturan lain untuk melaksanakan otonomi dan tugas pembantuan (Pigome, 2011). Dalam reformasi Pembentukan hukum meskipun melibatkan masyarakat dalam setiap aktivitas pembangunan kontribusi peraturan Tentang Pembentukan Peraturan Perundang-undangan belum dapat melahirkan produk hukum berupa Peraturan daerah yang dapat meningkatkan kesejahteraaan masyarakat (Setiadi, 2012). Untuk dapat meningkatkan kesejahteraan masyarakat seyogiannya Pembentukan Peraturan daerah dirumuskan secara demokrasi lebih transparan, partisipasi serta berkeadilan sehingga Peraturan daerah yang dibuat dan bagaimana isinya dan arahnya harus realitas sesuai dengan kebutuhan masyarakat demi terciptanya kesejahteraan masyarakat (Rodiya, 2012)

Perlunya Peraturan daerah ditata dengan baik dalam prespektif Pembangunan hukum yang demokratis mengingat selama ini berkembang isu-isu ditengah masyarakat bahwa produk hukum didalamnya banyak memuat kepentingan penguasa (elitis) tidak mempunyai nilai keadilan yang berpihak kepada masyarakat dan banyak yang tumpang tindih baik dari segi isi maupun bentuk pengaturannya (Gunawan, 2019). Peran serta tidak cukup hanya dilakukan oleh sekelompok orang yang duduk di lembaga perwakilan, mereka sering menggunakan poliitk atas nama kepentingan rakyat namun sebenarnya untuk kepentingan dirinya, kelompoknya dan bahkan untuk kepentingan partainya (Nugraha, 2016) (Bunga, et.al, 2018). Seluruh masukan-masukan dari masyarakat merupakan aspirasi telah tercurahkan dan aspirasinya dinyatakan telah diterima namun, keputusan tetap ada pada mereka. Seyogianya, jika anggota dewan memahami makna keikut sertaan masyarakat setidaknya ada legitimasi pada Pembentukan Peraturan daerah dan bagi eksekutif (pemerintah) setidaknya, telah membangun sumber daya masyarakat dalam pembaharuan/reformasi hukum hukum (Wirawan \& Nurpratiwi, 2015).

Penyelenggaran pemerintahan yang demokratis rakyatlah yang berdaulat dan kedaulatan rakyat itu dilaksanakan sesuai dengan hukum yang berlaku, yaitu hukum yang sesuai dengan kebutuhan masyarakat yang tercermin dalam Undang-Undang Dasar Negara Republik Indonesia 1945 sebagai pedoman dalam negara yang menghendaki agar Peratuan Perundangundangan dibuat secara demokratis, berkeadilan sosial dan berperikemanusian serta mengakomodir Kebhinekaan dalam bingkai Negara Kesatuan Indonesia (Asshiddiqie, 2008).

Perarturan Daerah merupakan peraturan perudang-undangan tingkat daerah, dibentuk oleh lembaga pemerintah di tingkat daerah dalam rangka penyelenggaraan otonomi daerah yang secara tegas ada dalam Pasal 18 ayat (6) UUD 1945 yang keberadaannya ada dalam sistem hukum di negara Republik Indonesia.3 Pasal 136 UndangUndang No. 32 Tahun 2004, mengatakan Perda dibentuk dalam kerangka penyelenggaraan otonomi daerah provinsi/kabupaten/ kota dan tugas pembantuan, merupakan penjabaran dari peraturan perundangundangan yang lebih tinggi dengan memperhatikan ciri khas masingmasing daerah (Yusdiyanto, 2014).

Praktik yang terjadi selama ini, dalam proses Pembentukan Peraturan daerah, peran masyarakat masih bersifat parsial dan simbolis. Beberapa komunikasi massa yang dilakukan hanyalah sebagai pelengkap prosedur adanya basic reaserch yang melandasi perencanaan Pembentukan Peraturan daerah (Bunga, 2020). Kemudian dalam tahapan pembahasan, 
masyarakat yang sudah mewakilkan kekuasaannya pada wakil rakyat di DPRD tidak lagi mendapatkan hak bicara. Sidang paripurna anggota dewan memang terbuka tetapi dibatasi oleh oleh protokol dan tata tertib DPRD sementara masyarakat menjadi tidak puas (Sosilowati, 2018).

Kaitan dengan hal tersebut, penelitian ini merumuskan permasalahan yaitu, Bagaimanakah implementasi peran serta masyarakat dalam Pembentukan Peraturan daerah di Kota Makassar? Faktor-faktor apa yang mempengaruhi implementasi Peran serta masyarakat dalam Pembentukan Peraturan daerah di Kota Makassar? Untuk menganalisa dan menjelaskan implementasi Peran serta masyarakat dalam Pembentukan Peraturan daerah di Kota Makassar. Untuk menganalisa dan menjelaskan faktor-faktor yang mempengaruh implementasi peran serta masyarakat dalam Pembentukan Peraturan daerah di Kota Makassar.

Pembentukan Peraturan daerah merupakan aturan yang mengikat secara hukum bagi masyarakat yang berdomisili di Provinsi maupun Kabupaten/Kota (Muhdar \& Jasmaniar, 2020). Dalam Pembentukan Peraturan Perudang-undangan diatur tentang tahapan pembentukannya yakni perencanaan, penyusunan, pembahasan dan pengesahan serta pengundangan. Pasal 96 ayat (1), (2), (3) dan (4) Undang-Undang Nomor 12 Tahun 2011Tentang Pembentukan Peraturan Perundang-undangan mengatur Tentang peran serta masyarakat dalam Pembentukan Peraturan daerah (Yusdiyanto, 2014). Dalam kaitan ini, peran serta masyarakat hanya dijalankan dan dijadikan oleh Pemerintah dan DPRD sebagai hal yang bukan substansi dengan kata lain hanya dijadikan sebagai pemenuhan pra syarat dan pelengkap dalam melaksanakan ketentuan sebagaimana Pasal 96 ayat (1), (2), (3) dan (4) Undang-Undang Nomor 12 Tahun 2011 Tentang Pembentukan Peraturan Perundangundangan.

Berdasarkan pemikiran yang demikian peran serta masyarakat menjadi tidak bermakna. Berbagai pemikiran dan teori yang berkembang menjadikan peran serta masyarakat dalam Pembentukan Perundang-undangan setidaknya memberikan legitimasi yang kuat bagi pemeintah dan DPRD sebagai wujud dari pelaksanaan sistem negera demokrasi. Namun disatu sisi Undang-Undang yang ada memberi batasan pelibatan masyarakat dalam Pembentukan Peraturan Perudang undangan. Dalam Negara Demokrasi keikutsertaan masyarakat dalam setiap proses pembangunan hukum khususnya sangatlah penting. Masyarakatlah yang merasakan dampak dari proses pembangunan

\section{METODE PENELITIAN}

Tipe penelitian ini menggunakan penelitian hukum Normatif mengkaji aturan-aturan yang berkaitan dengan Notaris dalam pembuatan akta autentik dan akta lain yang diatur dalam undang-undang. Bahan hukum adalah kumpulan bahan/sumber/data yang dijadikan analisis terdapat suatu tulisan yang saling berkaitan antara bahan hukum primer, bahan hukum sekunder dan bahan hukum tersier. Metode yang digunakan dalam pengumpulan bahan hukum adalah melalui pengkajian terhadap Kitab Undang-undang Hukum Perdata, peraturan perundang-undangan yang lain berkaitan dengan Jabatan Notaris serta kode etik Notaris sebagai bahan hukum primer serta melakukan penelusuran cermat terhadap berbagai bahan hukum berupa buku-buku hukum dan jurnal hukum untuk melengkapi bahan hukum, 
dilakukan wawancara dengan notaris. Selain itu dilakukan pula penelusuran bahan hukum melalui internet.

\section{PEMBAHASAN}

\section{A. Implementasi Peran Serta Masyarakat Dalam Pembentukan Peraturan Daerah Di Kota Makassar.}

Proses pembentukan peraturan daerah (perda) berdasarkan alur legislatif dan alur eksekutif Pada umumnya masyarakat tidak dapat mengikuti proses dalam arti peran serta kecuali dalam tahap pembahasan di Pansus. Dengan demikian dalam kesimpulan pembentukan Ranperda menjadi Perda dilakukan pada tahap sebelum atau diusulkan oleh pemrakarsa oleh pemerintah kota, pada tahap pembahasan pansus dan pada tahap sosialisasi oleh pemerintah kota.

Berdasarkan hasil penelitian yang dilakukan pada pemerintah kota Makassar dan DPRD menunjukkan bahwa peran serta masyarakat dalam pembentukan Perda hanya sebatas pada pembahasan di Pansus dan turut serta dalam sosialisasi.

Tabel 1.

Daftar Peraturan Daerah Tahun 2010-2015 Kota Makassar

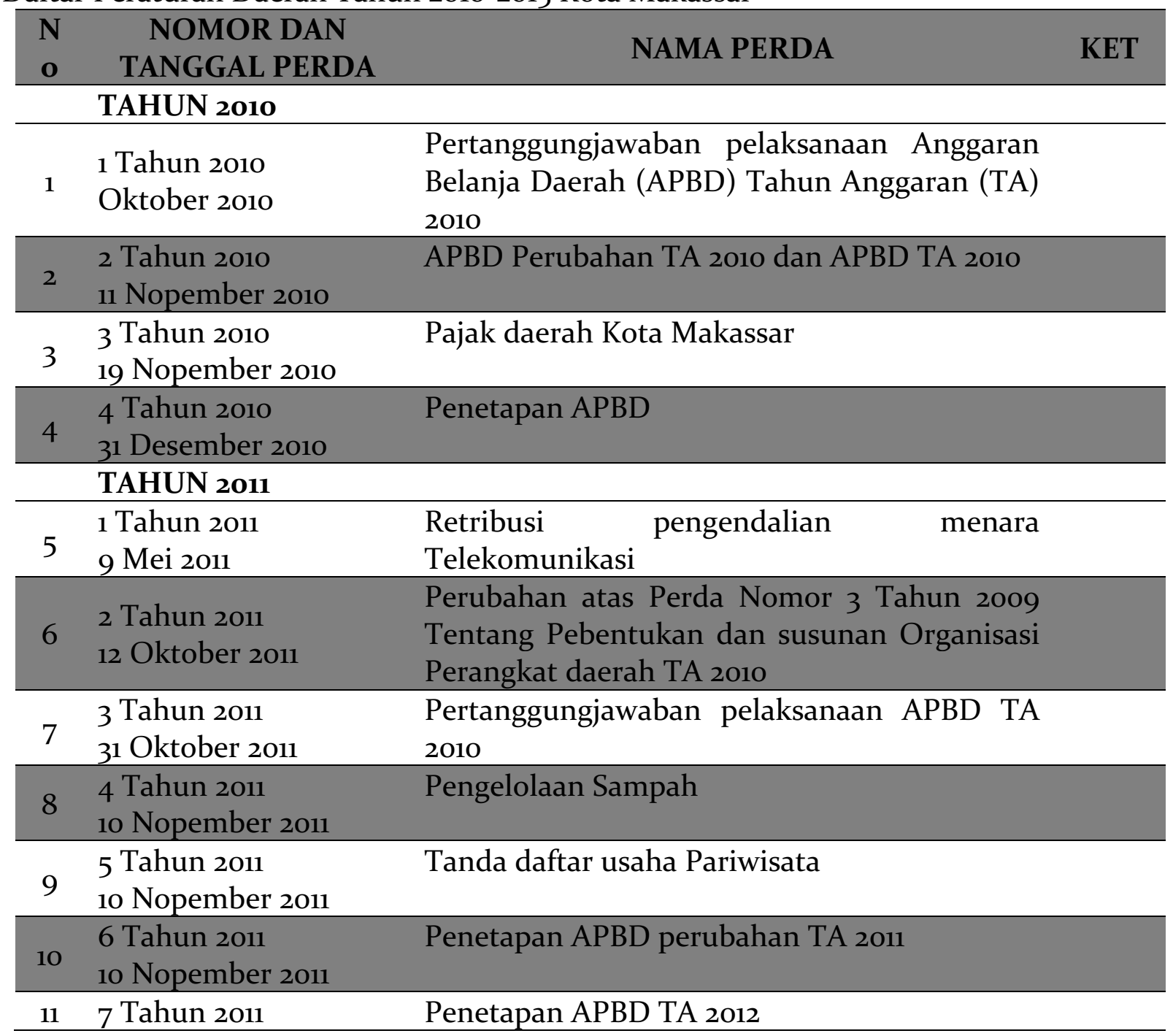


29 Nopember 2011

\begin{tabular}{|c|c|c|c|}
\hline 12 & $\begin{array}{l}8 \text { Tahun } 2011 \\
29 \text { Nopember } 2011\end{array}$ & Pembentukan dana cadangan & \\
\hline 13 & $\begin{array}{l}9 \text { Tahun } 2011 \\
\text { 3oDesember } 2011\end{array}$ & $\begin{array}{l}\text { Penyediaan dan penyerahan prasarana,utiltas } \\
\text { pada kawasan industri,perdagangan }\end{array}$ & \\
\hline 14 & $\begin{array}{l}\text { 10 Tahun } 2011 \\
\text { 30Desember } 2011\end{array}$ & Pengelolaan rumah kost & \\
\hline 15 & $\begin{array}{l}11 \text { Tahun } 2011 \\
\text { 3oDesember } 2011\end{array}$ & Restribusi kebersihan/persampahan & \\
\hline 16 & $\begin{array}{l}12 \text { Tahun } 2011 \\
30 \text { Desember } 2011\end{array}$ & Restribusi jasa umum & \\
\hline 17 & $\begin{array}{l}13 \text { Tahun } 2011 \\
30 \text { Desember } 2011\end{array}$ & Restribusi Jasa Usaha & \\
\hline & TAHUN 2012 & & \\
\hline 18 & $\begin{array}{l}\text { Tahun } 2012 \\
30 \text { April } 2012\end{array}$ & Pendidikan dan baca tulis $\mathrm{Al}$ qur'an & \\
\hline 19 & $\begin{array}{l}2 \text { Tahun } 2012 \\
22 \text { Mei } 2012\end{array}$ & $\begin{array}{l}\text { Perubahan Perda } 3 \text { Tahun } 2010 \text { tentang Pajak } \\
\text { daerah Kota Makassar }\end{array}$ & \\
\hline 20 & $\begin{array}{l}3 \text { Tahun } 2012 \\
18 \text { September } 2012 \\
\end{array}$ & $\begin{array}{l}\text { Pertanggungjawaban pelaksanaan APBD TA } \\
2011\end{array}$ & \\
\hline 21 & $\begin{array}{l}4 \text { Tahun } 2012 \\
29 \text { Oktober } 2012\end{array}$ & $\begin{array}{l}\text { Penetapan APBD perubahan Kota Makassar TA } \\
2012\end{array}$ & \\
\hline 22 & $\begin{array}{l}5 \text { Tahun } 2012 \\
\text { Mei } 2012 \\
\end{array}$ & Retribusi izin tertentu & \\
\hline 23 & $\begin{array}{l}6 \text { Tahun } 2012 \\
\text { Mei } 2012\end{array}$ & $\begin{array}{l}\text { Penambahan modal BPR daerah Kotamadya } \\
\text { Makassar }\end{array}$ & \\
\hline 24 & $\begin{array}{l}7 \text { Tahun } 2012 \\
\text { Mei } 2012\end{array}$ & Penetapan APBD Kota Makassar TA 2013 & \\
\hline & TAHUN 2013 & & \\
\hline 25 & $\begin{array}{l}1 \text { Tahun } 2013 \\
24 \text { Juli } 2013\end{array}$ & $\begin{array}{l}\text { Penataan dan pengendalian pembangunan } \\
\text { menara telekomunikasi }\end{array}$ & \\
\hline 26 & $\begin{array}{l}2 \text { Tahun } 2013 \\
1 \text { Agustus } 2013\end{array}$ & Pelestarian Cagar Budaya & \\
\hline 27 & $\begin{array}{l}3 \text { Tahun } 2013 \\
1 \text { Agustus } 2013\end{array}$ & Pertanggungjawaban APBD than 2012 & \\
\hline 28 & $\begin{array}{l}4 \text { Tahun } 2013 \\
30 \text { Desember } 2013 \\
\end{array}$ & Kawasan tanpa rokok & Ya \\
\hline 29 & $\begin{array}{l}5 \text { Tahun } 2013 \\
9 \text { September } 2013\end{array}$ & Penetapan APBD perubahan 2013 & \\
\hline 30 & $\begin{array}{l}6 \text { Tahun } 2013 \\
13 \text { Desember } 2013\end{array}$ & Pemenuhan penyandang Disabilitas & Ya \\
\hline 31 & $\begin{array}{l}7 \text { Tahun } 2013 \\
13 \text { April } 2013\end{array}$ & Pembentukan struktur organisasi & \\
\hline 32 & $\begin{array}{l}8 \text { Tahun } 2013 \\
19 \text { Desember } 2013 \\
\text { TAHUN } 2014\end{array}$ & APBD Pokok TA 2014 & \\
\hline
\end{tabular}




\begin{tabular}{|c|c|c|}
\hline 33 & $\begin{array}{l}1 \text { Tahun } 2014 \\
\text { Agustus } 2014\end{array}$ & Pertanggungjawaban APBD TA 2013 \\
\hline 34 & $\begin{array}{l}2 \text { Tahun } 2014 \\
5 \text { September } 2014\end{array}$ & APBD perubahan Kota Makassar TA 2014 \\
\hline 35 & $\begin{array}{l}3 \text { Tahun } 2014 \\
5 \text { September } 2014\end{array}$ & Penataan dan pengelolaan ruang terbuka hijau \\
\hline 36 & $\begin{array}{l}4 \text { Tahun } 2014 \\
5 \text { September } 2014\end{array}$ & $\begin{array}{l}\text { Pengawasan dan pengendalian } \\
\text { pengadaan,peredaran dan penjualan minuman } \\
\text { berakohol. }\end{array}$ \\
\hline 37 & $\begin{array}{l}5 \text { Tahun } 2014 \\
28 \text { Nopember } 2014\end{array}$ & $\begin{array}{l}\text { Rencana pembangunan jangka menengah } \\
\text { daerah Kota Makassar TA 2014-2019 }\end{array}$ \\
\hline 38 & $\begin{array}{l}6 \text { Tahun } 2014 \\
29 \text { desember } 2014\end{array}$ & Penetapan APBD TA 2015 \\
\hline & TAHUN 2015 & \\
\hline 39 & $\begin{array}{l}1 \text { Tahun } 2015 \\
21 \text { Agustus } 2015\end{array}$ & Laporan Pertanggungjawaban APBD TA 2014 \\
\hline 40 & $\begin{array}{l}2 \text { tahun } 2015 \\
9 \text { September } 2015\end{array}$ & $\begin{array}{l}\text { Pembentukan kelurahan Minasaupa,kelurahan } \\
\text { Bonto Duri,kelurahan Biring Romang, } \\
\text { kelurahan Bitowa,kelurahan Laikang }\end{array}$ \\
\hline 41 & $\begin{array}{l}3 \text { Tahun } 2015 \\
9 \text { September } 2015\end{array}$ & $\begin{array}{lll}\text { Pembentukan } & \text { kecamatan } & \text { Kepulauan } \\
\text { Sangkarrang } & & \\
\end{array}$ \\
\hline 42 & $\begin{array}{l}4 \text { Tahun } 2015 \\
3 \text { Nopember } 2015 \\
\end{array}$ & RTRW Kota Makassar Tahun 2015-2034 \\
\hline 43 & $\begin{array}{l}5 \text { Tahun } 2015 \\
16 \text { Nopember } 2015\end{array}$ & Perubahan APBD TA 2015 \\
\hline 44 & $\begin{array}{l}6 \text { Tahun } 2015 \\
29 \text { Desember } 2015\end{array}$ & Pengelolaan Air limbah Domestik \\
\hline 45 & $\begin{array}{l}7 \text { Tahun } 2015 \\
29 \text { Desember } 2015\end{array}$ & Penyelengaraan Bantuan Hukum \\
\hline 46 & $\begin{array}{l}8 \text { Tahun } 2015 \\
31 \text { Desember } 2015\end{array}$ & APBD Kota Makassar 2016 \\
\hline
\end{tabular}

Berdasarkan tabel di atas, jumlah peraturan daerah kota Makassar yang ditetapkan sebanyak 46 dalam kurun waktu 5 tahun terakhir terhitung sejak 2010 sampai dengan 2015. Akan tetapi keterlibatan masyarakat dalam pembentukan perda tidak terimplementasi dengan baik. Ini dibuktikan hanya ada tiga Perda yang ditetapkan terdapat keterlibatan masyarakat oleh karena dianggap mendapatkan perhatian dari masyarakat luas.

Perda disabiltas merupakan usulan dari NGO/LSM penyandang Disabilitas dari organisasi Persatuan Penyandang Disabilitas Indonesia (PPDI) Kota Makassar yang diajukan kepada walikota Makassar melalui kepala bagian hukum. NGO/SM sebagai kelompok yang representasi perwakilan masyarakat. Perda Kawasan Tanpa rokok tidak berjalan (operasional) alasannya tidak ada perwalinya namun selain itu pada saat dibentuk belum melibatkan masyarakat nanti pada saat pembahasan baru kelompok masyarakat sebagaimana di atas dilibatkan. 
Tabel 1. Nilai peran serta masyarakat.

\begin{tabular}{lcc}
\multicolumn{1}{c}{ Kategori } & Frekuency & Kumulatif \\
\hline Berperan & 16 & $20 \%$ \\
Tidak Berperan & 64 & $80 \%$ \\
\hline Total & 80 & $100 \%$ \\
\hline
\end{tabular}

Sumber Data: Hasil Penelitian yang dilakukan kepada seluruh responden.

Berdasarkan tabel di atas, bahwa nilai peran serta masyarakat dalam pembentukan peraturan daerah di kota Makassar menunjukkan hasil tidak berperan. Ini dibuktikan dengan 80 \% dari keseluruhan responden menjawab bahwa masyarakat tidak diikutsertakan dalam pembentukan peraturan tersebut. Pada umumnya hanya masyarakat tertentu yang diikutsertakan dalam pembentukan peraturan daerah tersebut seperti dari kalangan pengusaha ataupun lembaga swadaya masyarakat. Keikutsertaannya itu hanya pada tahap pembahasan saja dan pada tahap sosialisasi sedangkan pada tahap yang lain masyarakat (pengusaha atau LSM) tidak diikutsertakan.

\section{B. Faktor-Faktor Yang Mempengaruhi Implementasi Peran Serta Masyarakat Dalam Pembentukan Peraturan Daerah Di Kota Makassar}

Faktor yang mempengaruhi implementasi peran serta masyarakat dalam pembentukan peraturan daerah di kota Makassar adalah:

Tabel. 2. Jenis Kelamin Responden

\begin{tabular}{lcc}
\multicolumn{1}{c}{ Kategori } & Frekuency & Kumulatif \\
\hline Laki - laki & 52 & $65 \%$ \\
Perempuan & 28 & $35 \%$ \\
\hline Total & 80 & $100 \%$ \\
\hline
\end{tabular}

Sumber Data: Hasil Penelitian yang dilakukan kepada seluruh responden

Berdasarkan tabel di atas, jenis kelamin dapat menjadi faktor yang mempengaruhi implementasi peran serta masyarakat dalam pembentukan peraturan daerah di kota Makassar. Jenis kelamin Laki-laki menjadi dominan digunakan sebaga responden dalam penelitian ini dengan jumlah $65 \%$ dari jumlah keseluruhan respon. Hal ini membuktikan bahwa seluruh jumlah responden didominasi oleh laki-laki. Jumlah responden perempuan sebanyak $35 \%$ dari jumlah seluruh responden yang ada.

Tabel 3. Pendidikan Responden

\begin{tabular}{lcc|}
\multicolumn{1}{c}{ Kategori } & Frekuency & Kumulatif \\
\hline Sekolah Lanjutan Tingkat Pertama & 4 & $5 \%$ \\
Sekolah Lanjutan Tingkat Akhir & 20 & $25 \%$ \\
Strata Satu (S1) & 50 & $62,5 \%$ \\
Strata Dua (S2) & 4 & $5 \%$ \\
Strata Tiga (S3) & 2 & $2,5 \%$ \\
\hline Total & 80 & $100 \%$ \\
\hline
\end{tabular}

Sumber Data: Hasil Penelitian yang dilakukan kepada seluruh responden

Berdasarkan tabel di atas, bahwa pendidikan responden dapat menjadi faktor yang mempengaruhi implementasi peran serta masyarakat dalam pembentukan peraturan daerah di kota Makassar. Hasil penelitian menjelaskan bahwa semakin tinggi nilai pendidikan responden maka semakin berpengaruh responden tersebut dalam masyarakat tersebut. 
Persentasi pendidikan responden dengan kategori Starat Satu $\left(\mathrm{S}_{1}\right)$ dengan jumlah 62, $5 \%$ menjadi jumlah responden yang terbanyak dari seluruh kategori yang berkaitan dengan pendidikan.

Tabe 4. Pekerjaan Responden

\begin{tabular}{lcc}
\multicolumn{1}{c}{ Kategori } & Frekuency & Kumulatif \\
\hline Wiraswasta & 46 & $57,5 \%$ \\
Pegawai Negeri Sipil (PNS) & $\mathbf{2 2}$ & $\mathbf{2 7}, 5 \%$ \\
Mahasiswa & $\mathbf{2}$ & $\mathbf{2 , 5} \%$ \\
Praktisi & 10 & $\mathbf{1 2 , 5} \%$ \\
\hline Total & 80 & $100 \%$ \\
\hline
\end{tabular}

Sumber Data: Hasil Penelitian yang dilakukan kepada seluruh responden

Berdasarkan tabel di atas, pekerjaan responden dapat menjadi faktor yang mempengaruhi implementasi peran serta masyarakat dalam pembentukan peraturan daerah di kota Makassar. Hasil penelitian menjelaskan bahwa pekerjaan responden sangat berpengaruh untuk diikutsertakan dalam pembentukan peraturan daerah. Persentasi pekerjaan responden sebagai wiraswasta dengan jumlah 57,5 \% menjadi jumlah responden terbanyak dari seluruh responden berkaitan dengan pekerjaan.

Tabel 5. Nilai Substansi Hukum

\begin{tabular}{|c|c|c|}
\hline Kategori & Frekuency & Kumulatif \\
\hline Setuju & 20 & $25 \%$ \\
\hline Tidak Setuju & 60 & $75 \%$ \\
\hline Total & 80 & $100 \%$ \\
\hline
\end{tabular}

Sumber Data: Hasil Penelitian yang dilakukan kepada seluruh responden.

Berdasarkan tabel di atas dengan nilai substansi hukum dapat menjadi faktor yang mempengaruhi implementasi peran serta masyarakat dalam pembentukan peraturan daerah di kota Makassar. Hasil penelitian menjelaskan bahwa substansi hukum yang berkaitan dengan peraturan daerah yang dibuat oleh pemerintah kota Makassar tidak mendapat respon yang baik terhadap masyarakat kota Makassar. Ini dibuktikan dengan hasil persentasi yang menunjukkan bahwa $75 \%$ dari responden memilih tidak setuju terhadap diberlakukannya peraturan daerah oleh pemerintah kota Makassar. Penyebabnya adalah masyarakat tidak diberikan kesempatan untuk ikut serta dalam penyusunan peraturan daerah sehingga ada indikasi peraturan daerah yang dibuat tidak sesuai dengan keinginan masyarakat dan pada akhirnya peraturan daerah tersebut tidak dapat terlaksana dengan baik di masyarakat. Persentasi $25 \%$ bahwa responden setuju dengan diberlakukannya suatu peraturan daerah di kota Makassar dengan alasan bahwa responden tersebut ikut serta dalam pembentukan peraturan yang dibuat oleh pemerintah kota Makassar, meskipun hanya pada tahap pembahasan dan tahap sosialisasi peraturan daerah tersebut.

Tabel 6. Nilai Struktur Hukum

\begin{tabular}{|c|c|c|}
\hline Kategori & Frekuency & Kumulatif \\
\hline $\begin{array}{l}\text { Terlaksana } \\
\text { Tidak Terlaksana }\end{array}$ & $\begin{array}{l}16 \\
64\end{array}$ & $\begin{array}{l}20 \% \\
80 \%\end{array}$ \\
\hline Total & 80 & $100 \%$ \\
\hline
\end{tabular}

Sumber Data: Hasil Penelitian yang dilakukan kepada seluruh responden. 
Berdasarkan tabel di atas, nilai struktur hukum dapat menjadi faktor yang mempengaruhi implementasi peran serta masyarakat dalam pembentukan peraturan daerah di kota Makassar. Hasil penelitian menjelaskan bahwa struktur hukum berkaitan dengan kewenangan pemerintah dalam hal ini pemerintah kota Makassar dan DPRD Kota Makassar terhadap pemberian penyuluhan atau bimbingan kepada masyarakat berkaitan dengan keikutsertaan masyarakat dalam hal pembentukan peraturan daerah tidak terlaksana dengan baik. Ini menunjukkan bahwa 8o \% responden menjawab bahwa tidak ada penyuluhan yang diberikan oleh pemerintah kota Makassar dan DPRD kota Makassar berkaitan dengan kuikutsertaan masyarakat dalam pembentukan peraturan daerah di kota Makassar.

Persentasi $20 \%$ menunjukkan bahwa ada sebagian responden yang mendapat penyuluhan dan diikutsertakan oleh pemerintah dalam hal pembentukan peraturan daerah di kota Makassar. Responden yang dimaksud adalah NGO/pengusaha dan Lembaga Swadaya Masyarakat (LSM).

Tabel 7. Nilai Pengetahuan Masyarakat

\begin{tabular}{|c|c|c|}
\hline Kategori & Frekuency & Kumulatif \\
\hline Mengetahui & 35 & $43,8 \%$ \\
\hline Tidak Mengetahui & 45 & $56,2 \%$ \\
\hline Total & 80 & $100 \%$ \\
\hline
\end{tabular}

Sumber Data: Hasil Penelitian yang dilakukan kepada seluruh responden.

Berdasarkan tabel di atas, nilai pengetahuan masyarakat dapat menjadi faktor yang mempengaruhi implementasi peran serta masyarakat dalam pembentukan peraturan daerah di kota Makassar. Hasil penelitian menjelaskan bahwa masyarakat tidak mengetahui akan adanya peran serta dalam pembentukan peraturan daerah di kota Makassar, ini dibuktikan dengan persentasi responden menjawab tidak mengetahui sebanyak 56,2 \% dari seluruh jumlah responden.

Persentasi 43, 8 \% bahwa responden mengetahui adanya keikutsertaan masyarakat dalam hal pembentukan peraturan daerah di kota Makassar. Pada umumnya responden mengetahui hal tersebut bersumber dari informasi yang didapatkannya secara umum, bukan secara formal diberikan oleh pemerintah kota dan DPRD kota Makassar dalam bentuk seminar maupun sosialisasi.

Berdasarkan hasil penelitian yang dilakukan dihubungkan dengan teori hukum yang progresif, maka teori ini tidak sesuai dengan hasil penelitian yang dilakukan. Teori hukum progresif menghendaki hukum yang pro rakyat dan hukum yang prokeadilan akan tetapi, hasil penelitian menunjukkan bahwa peraturan perundangan-undangan yang dibuat sebagai produk hukum tidak sesuai dengan kehendak dan keinginan rakyat dan banyaknya peraturan perundang-undangan khususnya peraturan daerah kota Makassar yang menguntungkan beberapa pihak saja dan merugikan masyarakat secara umum.

Analisis terhadap implementasi peran serta masyarakat dalam pembentukan peraturan daerah kota Makassar adalah: 
Tabel 8. Jenis Kelamin Dihubungkan Dengan Peran Serta Masyarakat

\begin{tabular}{lccc}
\multirow{2}{*}{ Jenis Kelamin } & \multicolumn{2}{c}{ Peran Serta Masyarakat } & \multirow{2}{*}{ Total } \\
\cline { 2 - 3 } & Berperan & Tidak Berperan & \\
\hline Laki - Laki & 10 & 42 & 52 \\
Persentasi & $19,2 \%$ & $80,8 \%$ & $100 \%$ \\
Perempuan & 8 & 20 & 28 \\
Persentasi & $28,6 \%$ & $71,4 \%$ & $100 \%$ \\
Total & 18 & 62 & 80 \\
Persentasi & $22,5 \%$ & $77,5 \%$ & $100 \%$ \\
\hline
\end{tabular}

Sumber Data: Hasil Penelitian yang dilakukan kepada seluruh responden.

Berdasarkan tabel di atas, Analisis terhadap implementasi peran serta masyarakat dalam pembentukan peraturan daerah kota Makassar dihubungkan dengan jenis kelamin menunjukkan bahwa baik responden laki-laki maupun responden perempuan tidak berperan dalam pembentukan peraturan daerah tersebut. Ini dibuktikan dengan persentasi 8o, $8 \%$ dan $71,4 \%$ responden menjawab tidak ikut serta dalam pembentukan peraturan perundangoundangan yang berlaku khususnya di kota Makassar.

Persentasi yang berperan dengan jumlah 19, $2 \%$ dan 28, $6 \%$ menunjukkan bahwa pemerintah dalam hal ini pemerintah kota Makassar dan DPRD kota Makassar hanya memberikan kesepatan kepada pihak - pihak tertentu untuk ikut serta dalam pembentukan peraturan daerah tersebut.

Tabel 9. Pendidikan Responden Dihubungkan Dengan Peran Serta Masyarakat

\begin{tabular}{lccc}
\multirow{2}{*}{ Pendidikan Responden } & \multicolumn{2}{c}{ Peran Serta Masyarakat } & \multirow{2}{*}{ Total } \\
\cline { 2 - 3 } & Berperan & Tidak Berperan & \\
\hline Sekolah Lanjutan Tingkat Pertama & 1 & 3 & 4 \\
Persentasi & $25 \%$ & $75 \%$ & $100 \%$ \\
Sekolah Lanjutan Tingkat Atas & 2 & 18 & 20 \\
Persentasi & $10 \%$ & $90 \%$ & $100 \%$ \\
Starata Satu (S1) & 12 & 38 & 50 \\
Persentasi & $24 \%$ & $76 \%$ & $100 \%$ \\
Strata Dua (S2) & 0 & 4 & 4 \\
Persentasi & $\%$ & $100 \%$ & $100 \%$ \\
Starat Tiga (S3) & 1 & 1 & 2 \\
Persentasi & $50 \%$ & $50 \%$ & $100 \%$ \\
\hline Total & 16 & 66 & 80 \\
Persentasi & $20 \%$ & $80 \%$ & $100 \%$ \\
\hline
\end{tabular}

Sumber Data: Hasil Penelitian yang dilakukan kepada seluruh responden.

Berdasarkan tabel di atas, Analisis terhadap implementasi peran serta masyarakat dalam pembentukan peraturan daerah kota Makassar dihubungkan dengan pendidikan responden tidak berperan. Ini dibuktikan dengan jumlah keseluruhan 8o \% responden tidak berperan dalam pembentukan peraturan daerah tersebut. Dengan tingkatan pendidikan yang dimiliki oleh masyarakat, maka berdampak positif diikutsertakan dalam pembentukan peraturan daerah tersebut sehingga peraturan daerah yang dibentuk akan mudah untuk diaplikasikan oleh pemerintah dan masyarakat juga dapat melaksanakan peraturan daerah tersebut disebabkan norma yang ada dalam peraturan ini sesuai dengan keinginan dan perkembangan masyarakat tersebut. 
Persentasi $20 \%$ yang memberikan jawaban berperan dengan maksud bahwa responden tersebut diukutsertakan dalam pembentukan peraturan daerah kota Makassar, akan tetapi pada tahapan-tahapan tertentu saja yaitu pada tahap pembahasan rancangan peraturan daerah tersebut dan pada tahapan sosialiasi peraturan daerah tersebut, sehingga ada indikasi pemerintah kota Makassar dan DPRD kota Makassar dalam tahapan selanjutnya tidak memperhatikan usulan-usulan dari masyarakat tersebut. Pada tahap sosialisasi masyarakat yang diikutsertakan pada tahap pembahasan hanya dapat menerima hasil dari pembahasan rancangan peraturan daerah untuk dijadikan sebagai peraturan daerah kota Makassar. Masyarakat tidak memiliki kekuatan sebagai pemegang kedaulatan tertinggi dalam hal terbentuknya suatu peraturan daerah. Peraturan daerah tersebut dibentuk untuk masyarakat itu sendiri, akan tetapi masyarakat itu sendiri tidak mendapatkan peran yang lebih dalam pembentukan peraturan tersebut. Sehingga sangat lazim suatu peraturan daerah yan dibentuk tidak dapat diaplikasikan dalam masyarakat diakibatkan berbenturan dengan norma-norma yang ada dalam masyarakat itu sendiri.

Tabel 10. Pekerjaan Responden Dihubungkan Dengan Peran Serta Masyarakat

\begin{tabular}{lccc}
\multirow{2}{*}{ Pekerjaan Responden } & \multicolumn{2}{c}{ Peran Serta Masyarakat } & \multirow{2}{*}{ Total } \\
\cline { 2 - 3 } & Berperan & Tidak Berperan & \\
\hline Wiraswasta & 6 & 40 & 46 \\
Persentasi & $13,04 \%$ & $86,96 \%$ & $100 \%$ \\
Pegawai Negeri Sipil & 7 & 15 & 22 \\
Persentasi & $31,8 \%$ & $68,2 \%$ & $100 \%$ \\
Mahasiswa & 0 & 2 & 2 \\
Persentasi & $\%$ & $100 \%$ & $100 \%$ \\
Praktisi & 4 & 6 & 10 \\
Persentasi & $40 \%$ & $60 \%$ & $100 \%$ \\
\hline Total & 17 & 63 & 80 \\
Persentasi & $21,25 \%$ & $78,75 \%$ & $100 \%$ \\
\hline
\end{tabular}

Sumber Data: Hasil Penelitian yang dilakukan kepada seluruh responden.

Berdasarkan tabel di atas, Analisis terhadap implementasi peran serta masyarakat dalam pembentukan peraturan daerah kota Makassar dihubungkan dengan pekerjaan responden adalah tidak berperan. Ini dibuktikan dengan 78,75\% responden menjawab bahwa responden tidak diikutsertakan dalam pembentukan peraturan daerah tersebut. Apabila pekerjaan responden menjadi dasar pemerintah kota Makassar dan DPRD kota Makassar untuk diikutsertakan dalam pembentukan peraturan daerah maka sudah seharusnya untuk diikutsertakan. Akan tetapi, dari hasil penelitian yang dilakukan hal tersebut tidak terpenuhi. Dari semua kategori pekerjaan responden, hanya beberapa persen yang turut serta dalam pembentukan peraturan daerah tersebut.

Persentasi responden yang berperan dalam pembentukan peraturan daerah di Kota Makassar dengan jumlah 21, 25\% adalah persentasi yang sangat kurang dalam skala $100 \%$. Berdasarkan hasil penelitian, bahwa responden diikutsertakan tidak pada keseluruhan tahapan dalam pembentukan peraturan daerah. 
Tabel 11. Substansi Hukum Dihubungkan Dengan Peran Serta Masyarakat.

\begin{tabular}{lccc}
\multirow{2}{*}{ Substansi Hukum } & \multicolumn{2}{c}{ Peran Serta Masyarakat } & \multirow{2}{*}{ Total } \\
\cline { 2 - 3 } & Berperan & Tidak Berperan & \\
\hline Setuju & 15 & 45 & 60 \\
Persentasi & $25 \%$ & $75 \%$ & $100 \%$ \\
Tidak Setuju & 5 & 15 & 20 \\
Persentasi & $25 \%$ & $75 \%$ & $100 \%$ \\
Total & 20 & 60 & 80 \\
Persentasi & $25 \%$ & $75 \%$ & $100 \%$ \\
\hline
\end{tabular}

Sumber Data: Hasil Penelitian yang dilakukan kepada seluruh responden.

Berdasarkan tabel di atas, Analisis terhadap implementasi peran serta masyarakat dalam pembentukan peraturan daerah kota Makassar dihubungkan dengan substansi hukum adalah tidak berperan. Hasil penelitian menunjukkan bahwa $75 \%$ dari keseluruhan responden menjawab tidak berperan dalam pembentukan peraturan daerah kota Makassar.

Persentasi $25 \%$ adalah responden yang berperan dalam pembentukan peraturan daerah kota Makassar. Peranan tersebut dalam tahap pembahasan rancangan peraturan daerah dan sosialisasi peraturan daerah yang telah ditetapkan oleh pemerintah kota Makassar maupun DPRD kota Makassar.

\section{KESIMPULAN}

Implementasi peran serta masyarakat dalam Pembentukan Peraturan daerah di Kota Makassar belum terimplementasi dengan baik. Hal ini didasarkan bahwa dalam kurun waktu 5 tahun terakhir terhitung sejak 2010 sampai dengan 2015 sebanyak 46 peraturan daerah telah dibentuk dan hanya 3 peraturan daerah yang melibatkan masyarakat dalam pembentukan peraturan daerah tersebut serta bentuk keikutsertaan masyarakat tersebut hanya pada tahap pembahasan rancangan peraturan daerah dan sosialisasi peraturan daerah yang telah ditetapkan tersebut. Faktor-faktor yang mempengaruhi implementasi Peran serta masyarakat dalam Pembentukan Peraturan daerah di Kota Makassar adalah faktor pendidikan, faktor pekerjaan, faktor substansi hukum, faktor struktur hukum dan faktor pengetahuan masyarakat. Faktor tersebut menjadi hal utama dalam teralisasinya suatu peraturan daerah dengan baik khususnya peraturan daerah kota Makassar.

\section{SARAN}

Terhadap pemerintah kota Makassar dan DPRD kota Makassar untuk mengikutsertakan masyarakat dari berbagai golongan dalam pembentukan peraturan perundang-undangan dari tahap perancangan, tahap pembahasan hingga pada tahap penetapan dan sosialisasi dari peraturan tersebut. Terkhusus pada faktor pengetahuan masyarakat, pemerintah kota Makassar dan DPRD kota Makassar harus melakukan sosialisasi dan penyuluhan terhadap masyarakat berkaitan dengan peran serta masyarakat dalam pembentukan peraturan daerah di kota Makassar sehingga masyarakat mengetahui akan keikutsertaannya tersebut. 


\section{DAFTAR PUSTAKA}

Asshiddiqie, J. (2008, July). Membangun Budaya Sadar Berkonstitusi. In Bahan Seminar Membangun Masyarakat Sadar Konstitusi (Vol. 8, pp. 4-5).

Bunga, M. (2020). Model Pembentukan Peraturan Daerah Yang Ideal Dalam

Penyelenggaraan Otonomi Daerah. Jurnal Hukum E Pembangunan, 49(4), 818-833.

Bunga, M., Maroa, M. D., Arief, A., \& Djanggih, H. (2019). Urgensi Peran Serta Masyarakat Dalam Upaya Pencegahan Dan Pemberantasan Tindak Pidana Korupsi. Law Reform, 15(1), 85-97.

Gunawan, B. A. (2019). Tantangan Penjabaran Prinsip-prinsip Demokrasi dalam Pembentukan Peraturan Daerah. Al-Azhar Islamic Law Review, 1(2), 112-126.

Muhdar, M. Z., \& Jasmaniar, J. (2020). Studi Perbandingan A'borong (Musyawarah) Masyarakat Hukum Adat Kajang Dihubungkan Dengan PERMA Nomor: 1 Tahun 2016 Tentang Mediasi. PETITUM, 8(1 April), 57-70.

Nugraha, M. (2016). Partisipasi Masyarakat dalam Pembentukan Peraturan Daerah. YUSTISI, 3(1), 31.

Pigome, M. (2011). Implementasi Prinsip Demokrasi dan Nomokrasi dalam Struktur Ketatanegaraan RI Pasca Amandemen UUD 1945. Jurnal Dinamika Hukum, 11(2), 335348.

Rodiyah, R. (2012). Aspek Demokrasi Pembentukan Peraturan Daerah Dalam Perspektif Socio-Legal. Masalah-Masalah Hukum, 41(1), 144-152.

Setiadi, W. (2012). Pembangunan Hukum dalam Rangka Peningkatan Supremasi Hukum. Jurnal Rechts Vinding: Media Pembinaan Hukum Nasional, 1(1), 1-15.

Susilowati, E. (2018). Tingkat Keikutsertaan Masyarakat dalam Proses Pembentukan Undangundang. MORALITY: Jurnal Ilmu Hukum, 3(2), 46-58.

Wirawan, R., \& Nurpratiwi, R. (2015). Partisipasi masyarakat dalam perencanaan pembangunan daerah. JISIP: Jurnal Ilmu Sosial Dan Ilmu Politik, 4(2), 301-312.

Yusdiyanto, Y. (2014). Partisipasi Masyarakat Dalam Pembentukan Program Legislasi Daerah. FIAT JUSTISIA: Jurnal Ilmu Hukum, 5(2), 1-13 